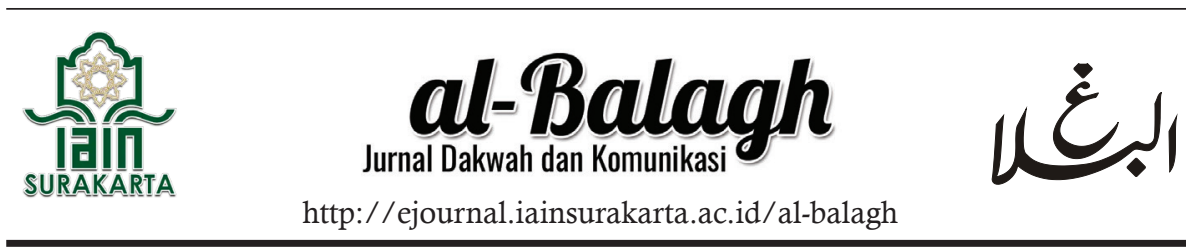

\title{
THE PORTRAYAL OF FEMALE CONVICTS IN THE NEWS REPORTING OF CANING EXECUTION IN ACEH
}

\author{
Ainal Fitri \\ Universitas Serambi Mekkah \\ Febri Nurrahmi* \\ Universitas Syiah Kuala
}

\section{Keywords: \\ Aceh; caning execution; female convict; online news}

\begin{abstract}
A prior observation indicated different portrayals of male and female convicts in caning execution news on five local online media in Aceh from 2018 until 2020. This study focuses on the emerging discourse surrounded female convicts. The study aims to discover the reality concerning context, production, text consumption, and social-cultural aspects influencing the discourse production within the text. This qualitative-descriptive study analyzed data from fifteen caning execution news, in-depth interviews with seven journalists, two editors, and one member of the Alliance of Independent Journalist Banda Aceh chapter (Aliansi Jurnalis Independen/AJI Banda Aceh). This study utilized Norman Fairclough's critical discourse analysis as the data analysis method. The findings revealed that the female convicts dominated news about caning, especially in khalwat and ikhtilat cases. Female convicts were represented as figures who violated social and moral norms, gender stereotypes, and expectations of femininity. This discourse benefited news organizations economically and also promoted discrimination against female convicts.
\end{abstract}

Correspondence:

e-mail: ainal.fitri@serambimekkah.ac.id *febri.nurrahmi@unsyiah.ac.id 


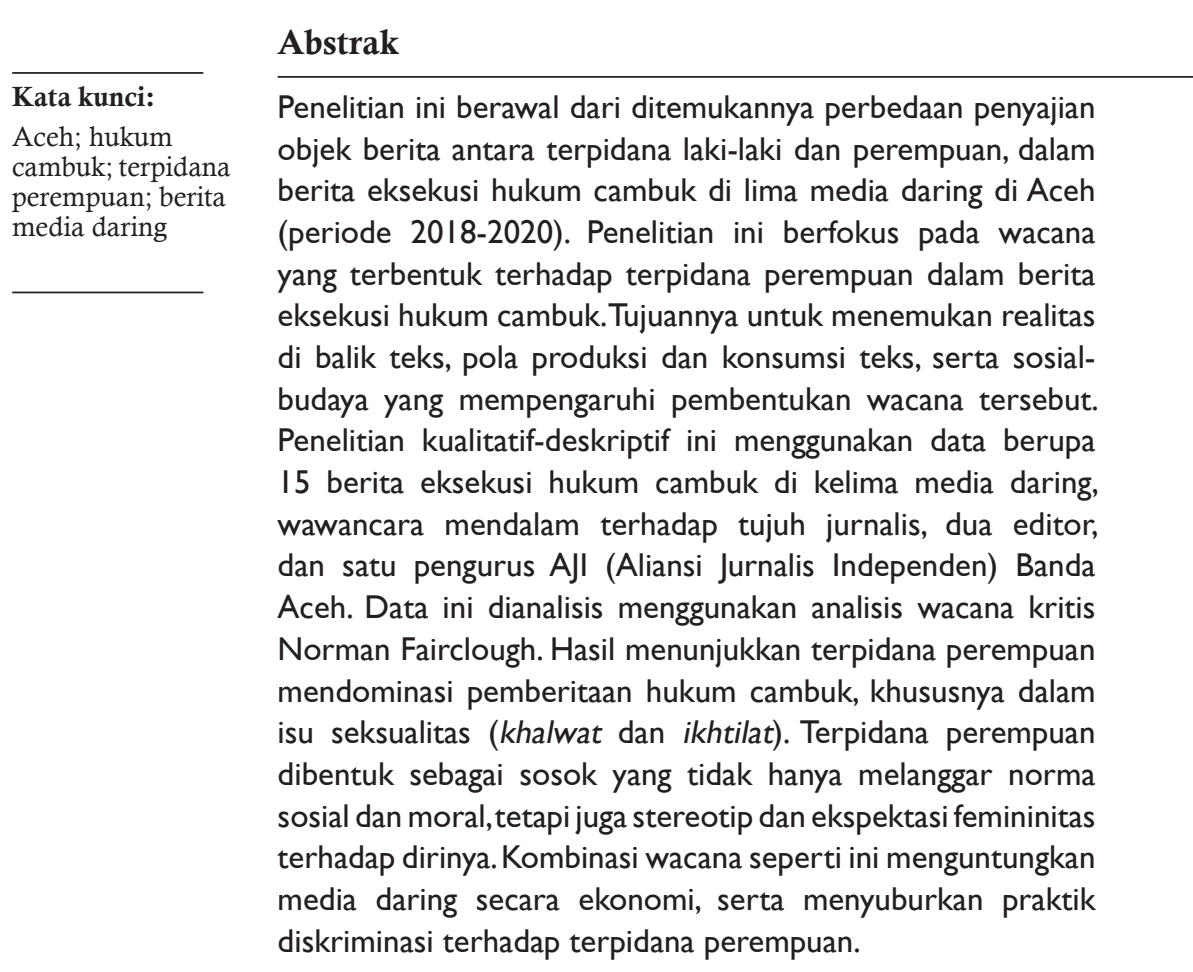

\section{How to cite this (APA 7th Edition):}

Fitri, A., \& Nurrahmi, F. (2021). The Portrayal Of Female Convicts In The News Reporting Of Caning Execution In Aceh. Al-Balagh: Jurnal Dakwah Dan Komunikasi, 6(1). 95 - 130, https://doi.org/10.22515/albalagh.v6i1.3061

\section{INTRODUCTION}

Since Aceh Province legalized Bylaws No. 6/2014, on Qanun Jinayah (Islamic Criminal Code), several crimes, including khamar (alcohol consumption), maisir (gambling), khalwat (segregation of unmarried couples), ikhtilath (intimacy between unmarried couples), zina (adultery 
and pre-marital sex), sexual harassment, rape, qadraf (falsely accusing someones of committing zinas), liwath (homosexuality), and musahaqah (lesbian) are subjects to caning. Despite the fact that this bylaw provides for other penalties such as financial restitution in gold or imprisonment, the caning execution has emerged as the most frequently prosecuted offense in Aceh. According to data published by the Government of Banda Aceh Municipality, from 2018-2020, there were 111 Sharia violation cases punished by caning in the city of Banda Aceh (Satpol PP \& WH Kota Banda Aceh, 2021). On another side, the data showed 147 cases punished by 'other penalties', although it did not clearly state the kind of punishment (financial penalty or imprisonment). As the capital city of Aceh Province, Banda Aceh's data could represent a more significant phenomenon in Aceh. The researchers assumed that many Sharia convicts choose this form of punishment because it is relatively inexpensive and timesaving compared to fine or imprisonment.

In addition, the high frequency and intensity of news reports of caning indicate that it was carried out more frequently. Caning is enforced in public places, and it is easily accessible to the media. This is different from paying a fine or imprisonment that is not executed in public spaces and is rarely exposed by media. The presence of online media makes the caning execution is more accessible for the public. Moreover, other platforms such as WhatsApp, Facebook, Twitter, and other social media, provide sharing features that enable users to share news and make it viral.

Generally, women are often represented by pictures or photos (eye candy), and men are represented by text and given more spaces (Jia, Lansdall-Welfare, Sudhahar, Carter, \& Cristianini, 2016). In crime stories, the discourse of women discourse also encounters many problems. The research of Brennan \& Vandenberg (2009) found that when women were involved in crimes, they did breach not only the law but also violated the expectation from their social environment. It further leads to the The Portrayal of Female Convicts in the News Reporting of Caning Execution in Aceh Ainal Fitri, Febri Nurrahmi 
news interests towards female offenders. The research of O'Donnell (2016) highlighted that despite male and female offenders experience discrimination through dehumanization practices carried by mass media, the female criminals always get more spotlight compared to the male.

In Indonesia's context, a woman who got involved in a murder case would be portrayed by mass media as a 'crazy' figure because she contradicted society's expectation of a woman as a graceful, wise, lovely, and patient person (Muktiyo, 2017). In corruption cases, female convicts were portrayed as erotic figures with a glamour lifestyle and depicted politics as a male territory and domesticated women (Hadiati, Abdullah, \& Udasmoro, 2013). Women who are not the primary perpetrators of crimes also face similar issues. For example, women who have close relationships with corruptors are presented as money-grubbers, prostitutes, helpless and 'cheap' widows, and sexually oriented dangdut singers (Dedees, 2014). Meanwhile, if the offenders are men, they will be depicted as husband, father, or entrepreneur, and rarely got media attention.

The positioning of women is constantly covered by patriarchy, discrimination, lack of empathy, or the assertion of a consumerism lifestyle (Murtiningsih \& Advenita, 2017). Besides, online media often frame women in politics, crimes, rape cases, sexual harassment, and even advertisement (Murtiningsih et al., 2017). In the context of Aceh, women are often put as a news angle and the central issue in the discourse of the Sharia Law compared to men (Maulina, 2017). That sort of discourse could endanger women's life. For example, in the report of Human Rights Watch (2010), a woman lost her job, friends, reputation, and family because of faulty news about her committing khalwat. It exemplified how discrimination practices, injustice, negative prejudice distributed by mass media can seriously affect the lives of individuals or society in general.

To the best of our knowledge, there is no study looking specifically at the discourse of crime, women, and Islamic law in Aceh on the news. 98 
Currently, caning and caning execution in Aceh are mainly studied from a legal perspective. In the context of media studies, research on caning and caning execution has been studied in general terms, such as the implementation of Sharia law (Bahri, 2013), the caning of gays Juliani, 2018), and photojournalism ethics (Fakhri \& Juanda, 2020). Meanwhile, the study about the portrayal of female convicts has not been found. The only research that shows the presence of women in the news about the caning execution is Amri (2019). His study analyzed 16 articles of Serambinews. com framing. It discovered eight forms of representation, including the caning protects women's rights: the caning discriminates against women; the caning is a light punishment; the pros and cons of caning in prisons; the caning gets appreciation from the community; the caning is a spectacle for tourists; the caning is a discriminatory law, and the caning does not affect investment in Aceh.

His research revealed media representations of women in Aceh's local online site. Firstly, Serambinews.com represents itself as a media that seeks to protect women, but this only applies if a woman is a victim. Secondly, women are still inseparable from media discrimination if a woman acts as a perpetrator. His study confirmed how media could have two faces in positioning women in media discourse.

Therefore, this study focused on the discourse of female convicts on caning execution news in five local online media corporations from 2018 until July 2020. It has three objectives. Firstly, it is intended to find out how the female convict's representation, relationship, and identity in the news of the caning execution are formed. Secondly, it aims to uncover the production and consumption scheme of the text. Thirdly, it attempts to locate the relationship between the legal discourse on online media against the socio-cultural context. This discourse has implications for forming dominant knowledge for readers, media, stakeholders, and other related parties regarding the law of caning and female convicts. In doing so, this 
study attempts to fill this gap by focusing on how online media shape the discourse of female convicts in the news of the caning execution. It is expected to be preliminary research for future studies that have similar interests in the discourse of women, crime, Islamic law, and mass media.

This research was studied using the concept of power relations by Michel Foucault. Kristensen (2013) explained that according to Foucault, power is understood as a form of relation and how the power relation works. Authority is the power that can strengthen the relationships involved or even isolate a connection. There are at least five propositions related to power: power is exercised in line with relationships that continuously evolve because power is reciprocal in nature; power relations prevail where these relations operate; power explains that there is no binary opposition (oppositional opposition) between those who control and are controlled; power relations are intentional and non-subjective. Power is related to knowledge; power can never be separated from knowledge, where combining the two results in discourse. Knowledge itself is not pure and neutral, but the knowledge legitimized by authority becomes a form of normalization of power in society. The discourse that is formed by the mass media is certainly not free from values. Littlejohn \& Foss (2009) explained that the media have economic, politicals, and other interests. This leads the media to have power in constructing a reality according to its claims. Each preference of words, sentences, language is not value-free. Journalists and editors have a strategic role in determining these strategic choices.

\section{METHODS}

This research used a qualitative descriptive approach using the critical paradigm. This paradigm helps to discover a framework for how an idea is constructed and how the impact on the power structure prevails in reality (Littlejohn \& Foss, 2009). Data were sourced from online news 
articles, interviews, and readers' comments. Firstly, data from news articles included 15 news articles of the caning execution in five local online media (see Table 1). The researchers examined how some online media reported the exact caning executions.

Table 1.

Sample For Textual Analysis

\begin{tabular}{|c|c|c|c|}
\hline No & Media & Edition & Title \\
\hline 1 & AJNN.net & 20-04-18 & $\begin{array}{l}\text { Banda Aceh City Officials Implements Caning } \\
\text { Execution in Front of the Mosque (Pemko } \\
\text { Banda Aceh Laksanakan Hukuman Cambuk Di } \\
\text { Depan Masjid) }\end{array}$ \\
\hline 2 & Serambinews.com & 20-04-18 & $\begin{array}{l}\text { Caning Execution Completed, This is What } \\
\text { the Deputy Mayor Said about the Caning } \\
\text { Controversy in the Open Field (Uqubat } \\
\text { Cambuk Selesai, Ini Kata Wakil Walikota Soal } \\
\text { Kontroversi Cambuk Di Lapangan Terbuka) }\end{array}$ \\
\hline 3 & MODUSACEH.CO & 20-04-18 & $\begin{array}{l}\text { Two of the Prisoners of Online PSK Caned } \\
\text { (Dua Terpidama PSK Online Dicambuk) }\end{array}$ \\
\hline 4 & Serambinews.com & 20-09-18 & $\begin{array}{l}\text { Today there are caning executions of } 18 \\
\text { Sharia Law violators in West Aceh (Hari Ini } \\
\text { Ada Eksekusi Cambuk Terhadap } 18 \text { Pelanggar } \\
\text { Qanun Di Aceh Barat) }\end{array}$ \\
\hline 5 & MODUSACEH.CO & 20-09-18 & $\begin{array}{l}\text { Violating Sharia Law, they were flogged after } \\
\text { (Melanggar Syariat Islam Mereka Dicambuk) }\end{array}$ \\
\hline 6 & Waspadaaceh.com & 20-09-18 & $\begin{array}{l}\text { In pain, the caning of the Sharia Law violators is } \\
\text { postponed (Kesakitan, Eksekusi Cambuk Terpidana } \\
\text { Pelanggar Qanun Ditunda) }\end{array}$ \\
\hline 7 & Beritakini.co & $29-10-18$ & $\begin{array}{l}\text { Make out with the receptionist, the Manager } \\
\text { of Rumoh PMI Hotel Caned (Mesum Dengan } \\
\text { Resepsionis Penanggungjawab Hotel Rumoh PMI } \\
\text { Dicambuk) }\end{array}$ \\
\hline 8 & Waspadaaceh.com & $29-10-18$ & $\begin{array}{l}\text { Hotel Managers and Employees Caned } 52 \\
\text { Times in Banda Aceh (Manajer Dan Karyawan } \\
\text { Hotel Dicambuk.52 Kali Di Banda Aceb) }\end{array}$ \\
\hline 9 & Serambinews.com & 02-08-19 & $\begin{array}{l}\text { Darwati groaned when the executioner } \\
\text { flogged her (Darwati Merintib saat Dicambuk } \\
\text { Algojo) }\end{array}$ \\
\hline
\end{tabular}


Al-Balagh: Jurnal Dakwah dan Komunikasi,

Vol. 6, No. 1, January - June 2021, pp. 95 - 130, DOI: https://doi.org/10.22515/al-balagh.v6i1.3061

ISSN: 2527-5704 (P) ISSN: 2527-5682 (E)

\begin{tabular}{|c|c|c|c|}
\hline No & Media & Edition & Title \\
\hline 10 & MODUSACEH.CO & 02-08-19 & $\begin{array}{l}\text { The fourth lash, Female Convict Grimaced } \\
\text { with Pain(Pukulan Keempat Terpidana Perempuan } \\
\text { Hukuman Cambuk Meringis Kesakitan) }\end{array}$ \\
\hline 11 & Serambinews.com & 07-04-2020 & $\begin{array}{l}\text { Wife of former DPRK member of } \\
\text { Subulussalam Caned } 22 \text { Times, Here's how } \\
\text { the Case Goes (Istri Mantan Anggota DPRK } \\
\text { Subulussalam Dicambuk. } 22 \text { Kali, Begini Perjalanan } \\
\text { Kasusnya) }\end{array}$ \\
\hline 12 & Beritakini.co & 07-04-2020 & $\begin{array}{l}\text { Cheating with the Chairman of Election } \\
\text { Committee, Former Wife of DPRK Member } \\
\text { Subulussalam Lashed } 22 \text { times (Selingkuh } \\
\text { dengan Ketua Panwaslih, Mantan Istri Anggota } \\
\text { DPRK Subulussalam Dicambuk.22 kali) }\end{array}$ \\
\hline 13 & Serambinews.com & $17-04-2020$ & $\begin{array}{l}\text { Entangled in the case of immorality, a non- } \\
\text { Mahram couple in Aceh Caned, a female } \\
\text { convict is a teacher (Terjerat Kasus Asusila } \\
\text { Pasangan Bukan Mubrim di Aceh Dicambuk, } \\
\text { Terpidana Perempuan Seorang Guru) }\end{array}$ \\
\hline 14 & Beritakini.co & $17-04-2020$ & $\begin{array}{l}\text { A Coupleof Sharia Offenders Caned in } \\
\text { Simeulue (Pasangan Pelanggar Syariat Dicambuke } \\
\text { di Simeulue) }\end{array}$ \\
\hline 15 & MODUSACEH.CO & $17-04-2020$ & $\begin{array}{l}\text { The Impact of Corona Virus, Caning } \\
\text { Execution Held in Prisons (Dampak Corona } \\
\text { Eksekusi Cambuk Digelar di Lapas) }\end{array}$ \\
\hline
\end{tabular}

Secondly, seven journalists and two editors from the five online media were interviewed. This selection of participants is based on the experience of journalists and editors in the news production of caning during the selected timeframe periods. Due to the sensitive nature of this topic, all participants remained anonymous as outlined in the consent form. The form aims to explain how the researcher maintains the privacy and anonymity of informants (Dawson, 2014). All participants were provided with participant numbers (J1-J7 for journalists and E1-E2 for editors). In addition to the interviews with the journalists and editors, the interview was also conducted with a representative of Banda Aceh Independent 
Journalist Alliance (Aliansi Jurnalis Independen/AJI Banda Aceh) 20182021. This study used a semi-structured interview format. This technique allows the researcher to position a particular issue in the question while providing opportunities for informants to develop their answers or ideas more independently (Rabionet, 2011). Thirdly, to determine the media consumption pattern of readers, the researchers observed the comments given by readers towards the selected news stories in five online media portals.

The data obtained were analyzed using the critical discourse analysis (CDA) method, the dialectical-relational approach model by Norman Fairclough. Fairclough's critical discourse analysis aims to discover the reality behind the female convicts by exploring the production context, text consumption, and socio-cultural aspects that affected text creation. CDA relies on the presumption that discourse is not understood as plainly a series of words or propositions in a text, but something that produces something else (an idea, concept, or effect) (Fairclough \& Fairclough, 2018). Referring to this technique, the researcher follows at least four stages: 1) Conducting normative criticism of discourse; 2) Explain the normative criticism following the prevailing values; 3) Explaining criticism of the real reflection and ongoing discourse; and 4) Advocating what steps can be taken to change the situation. CDA is based on discourse concerning power practices, knowledge, production of subjects and objects in text, speech, or images in social contexts and practices.

The data analysis techniques include micro, meso, and macro levels of analysis. Firstly, fifteen news data were analyzed (micro-level) using semiotic analysis by Ferdinand de Saussure. According to Saussure (Chiu \& Lu, 2015), text operates syntagmatically and paradigmatically. Syntagmatically, the researchers analyzed to find the relevant signs with the interview questions. Meanwhile, paradigmatically, the researchers interpreted the intrinsic and extrinsic meanings of the sentences The Portrayal of Female Convicts in the News Reporting of Caning Execution in Aceh 103 Ainal Fitri, Febri Nurrahmi 
constructed in the text and locate the relationships therein. This analysis was carried out to describe how the representations, relationships, and identities formed were related to female convicts in the caning execution news. The analysis results would contribute to depicting forms of social irregularities (discrimination, marginalization, objectification, etc.) through text.

Secondly, the meso-level analysis was performed through interviews with seven journalists and two editors by initially composing transcripts and codifying the informants' answers. This analysis aims to determine the cause of the irregularity that occurred. The researchers did not find any reader's comments on the fifteen news stories in five online media. Therefore, the researcher observed readers' comments through news links on each online media's Facebook fan pages. The researchers chose natural observation techniques, and the data obtained was codified based on readers' comments that led to male and female convicts.

Thirdly, macro-level analysis by transcribing and coding the interview with the secretary of AJI Banda Aceh. This analysis aims to explain whether the irregularities are desired by related relations within and outside the media context. This analysis is associated with situational, institutional, and social factors. The research results are presented descriptively to provide an overview of how the discourse of female convicts is formed in the caning execution news and its link with other subjects.

\section{RESULTS AND DISCUSSION}

\section{Representations Of Female Convicts In The News Of Caning Execution}

Representation is a prominent part of spotting how meaning through language is produced and exchanged with one another. According to Stuart Hall (Shaw, 2017), representation is how the use of language as a medium to convey specific ideas. Meanings can only be expressed through 104 
a system of representations and signs related to the meaning system. The representation of female convicts in this study can be comprehended through the attachment of female convicts to the issue of violating Islamic law, in this case, khalwat and ikhtilath. The existence of women in these two types of violations attracts the attention of the mass media to produce news. From 2018 to 2020, AJNN.Net, Serambinews.com, Modusaceh. com, Waspadaaceh.com, and Beritakini.co reported khalwat and ikhtilath by positioning female convicts as the primary object.

The different reportage between male and female convicts emerges in three aspects: firstly, the use of gendered headlines towards women; secondly, news angle and reporting; thirdly, the higher frequency of female offenders' photo use, regardless of the cases involving both genders. The representations of female convicts were illustrated by emphasizing the gender background of the convicts. It is evident in Modusaceh.co (02-08-19) and Serambinews.com (17-4-20), which included the word 'woman' in the title.

In 2020, Serambinews.com (07-04-2020) and Beritakini.co (07-042020) also employed the word 'wife' in news headlines. Serambinews.com even provided a considerable portion of coverage for this case. This news was broadcasted on four screens. The technique of presenting news information was also dramatized by linking female convicts with cheating, nasty chat, romantic, and scandalous. Serambinews.com also framed the news with several testimonies from witnesses who were presented at the previous trial.

The formation of information by Serambinews.com indicates that female convicts were represented as having a significant role in the act of khalwat. A further examination revealed that this representation was even formed long before the execution of caning was carried out. Female convicts were represented as those who liked to have sex and were responsible for the khalwat cases. Serambinews.com reinforced this message 
at the end of the news that the male convict admitted that he denied sending a message inviting her to do obscenity. Still, the female convict sent the seductive messages, but the male convict did not pay attention. Beritakini.co did not give this case a large portion in the same edition for a similar incident. This can be seen from the standard journalistic news presentation by implementing journalism's 5Ws (and an $\mathrm{H}$ ). The similarity in these two media is to attach the label of wife and affair to female convicts. The reporting of this case in Beritakini.co was recorded as distributed 230 times via the Facebook page.

Also, the five online media often emphasized additional information in the form of jobs carried out by female convicts. For example, the news of khalwat convicts on 17 April 2020 in Serambinews.com, Beritakini.co, and Modusaceh.com. The female convict was a teacher, and it was emphasized in all three media. On Beritakinico (17-04-20), this news has even been liked 1,100 times on the Facebook page. On Modusaceh.com (17-04-20), the background of the female convict as a teacher was also highlighted in the body of the news as mentioned below:

The couple, namely the man with the initials AA, along with AW, her female partner, is a teacher at one of the schools in Simeulue. Both of them were sentenced to be lashed 28 times (Modusaceh.com, 17 April 2020).

The researchers found a relationship that labels embedded in the media caused the position of female convicts to become more complicated. The press gave the impression that the female convict, a teacher, and a woman, broke normative expectations that teachers and women should not be involved in such a crime. This argument is in line with research by Brennan \& Vandenberg (2009), who found that women committing crimes were represented as not appropriate, while similar practices rarely occur when male convicts were involved. 
Another finding exhibited that female convict was also represented by several online media as weaker offender than male convict, for instance:

"However, when executing Mega, the executioner stopped at the fifth lash because the convict groaned." (Serambinews. com, 20 April 2018)

The choice of the word 'execute' by Serambinews.com represented the harsh punishment process that the convict must endure. However, when the word 'execute' was combined with the convict's name, 'Mega', Serambinews. com represented a female convict as less powerful, and the executioner is the one who has power. The word 'execute' could represent the Aceh government, Qanun Jinayah, or the executioner himself. Also, the word executioner represents a symbol of strength associated with men. This argument is based on the fact that at the end of 2019, all of the executioners on duty were men. Furthermore, the use of groaning represents the inability of female convicts to face the sentence. On the other hand, AJNN.Net and Modusaceh.com did not construct female convicts as weak figures in the coverage of a similar event.

However, in 2019, Modusaceh.com carried out a similar practice by publishing a story entitled 'Female Convicts Groaning in Pain after the Fourth Lashes.' In this publication, Modusaceh.com created the suffering experienced by female convicts as an interesting angle. The dramatization of this incident was described through the lead as follows:

"At the count of the fourth during the fourth lash, Dar immediately groaned in pain", and "the tears of the white woman immediately dripped, the caning execution was stopped." (Modusaceh.co, 2 August 2019)

The information on the inability of female convicts to serve a sentence is visible, with the addition of information at the end of the news that male convicts could serve sentences even while enduring pain. 
Likewise, Serambinews.com published a news story entitled 'Darwati groaned when the executioner was lashing her.' This media emphasized female convicts by providing an element of dramatization of the inability of female convicts to undergo execution. Serambinews.com even described it through the use of the sentence: "Darwati groaned in pain, with only four lashes." In 2020, the dramatization of female convicts was produced by the five media outlets. Serambinews.com (17-04-20) used the sentence "unable to hold back tears, and feels ashamed," Beritakini.co (17-04-20) typed the sentence "The female convict raised her hands several times because she felt pain, and after receiving a final lash, the officers had to carry her off the stage."

Female convicts were also represented as the second sex. Women are often used as the second subject whose position is not equal to men. The mass media could perpetuate gender norms and simultaneously shape the way audiences behave, following the values that media preserved (Wright \& Holland, 2014). This study found that female convicts experienced marginalization, which resulted in their figures being inseparable from male figures, who were considered more powerful. News stories on Alertaceh. com (29-10-18) and Beritakini.co (29-10-2018) reflected a hierarchical system between superior and subordinate in ibktilath cases. On the one hand, the manager was associated with the male convict, and on the other hand, the receptionist was linked with the female convict. The second sex attached to female subjects increasingly put women in a weak standpoint over themselves. This representation was influenced by patriarchal ideology. It further affects how the readers' knowledge conceived the male and female convicts.

Implicitly, Foucault (Graham, 2011) said that the form of power is reflected through the discourse regime. Discourse has autonomy and claims truth over knowledge. The claim of truth is an example of the practice of power, which can affect the groups whose relations are 108 
involved in it. According to Foucault (Graham, 2011), power should be based on how power operates and how power is exercised, not based on who has power and where the power comes from. Foucault added that power could not be seen explicitly.

Consequently, many subjects involved do not realize the impact of a prevailing power, even though the subject is unconsciously controlled over his body. This is in line with Fairclough's thinking that certain ideologies continue to be produced and reproduced for the sake of power. The goal is to provide existence to a certain ideology so that power relations will continue to last in the ongoing social structure.

The emergence of female convicts who dominate cases of sexuality forms a scheme as if khalwat and ikhtilat are always initiated by women, while men are engaged in other violations. Hegarty \& Bruckmüller (2013) explained that according to Foucault, the concept of power in modern society is in disciplinary power, which explains that the power owned by authority functions in the system multi-tiered social relationship. This makes a particular system applicable and considered a valid and rational objective. It seems that female convicts were normalized as violators of Sharia in cases of sexuality by the media. Power relations focus on normalizing behavior that is designed to take advantage of productive and reproductive abilities. This is aimed as a form of habituation and to place it as a medium of power (vehicle of power).

This relationship can also be seen through the differences in the presentation of photos of male and female convicts. From the results of this study, the researchers found that in 2018-2020, female convicts were more often used as the main photo object in reporting on caning compared to male convicts, especially in news of khalwat and ikhtilath. 
Al-Balagh: Jurnal Dakwah dan Komunikasi,

Vol. 6, No. 1, January - June 2021, pp. 95 - 130, DOI: https://doi.org/10.22515/al-balagh.v6i1.3061

ISSN: 2527-5704 (P) ISSN: 2527-5682 (E)

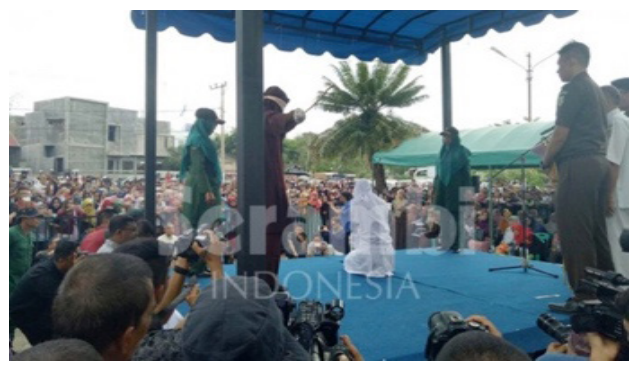

Photo 1. Serambinews.com (20 April 2018)

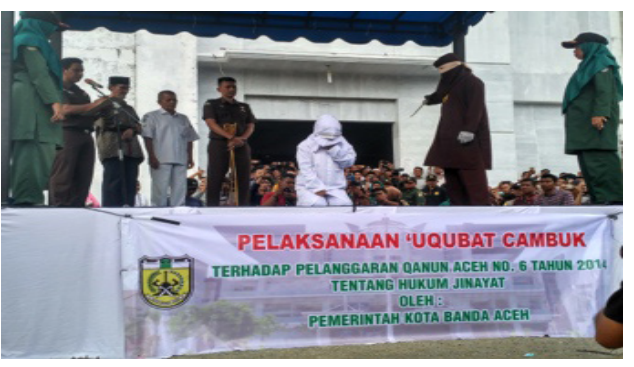

Photo 2. AJNN.net (20 April 2018)

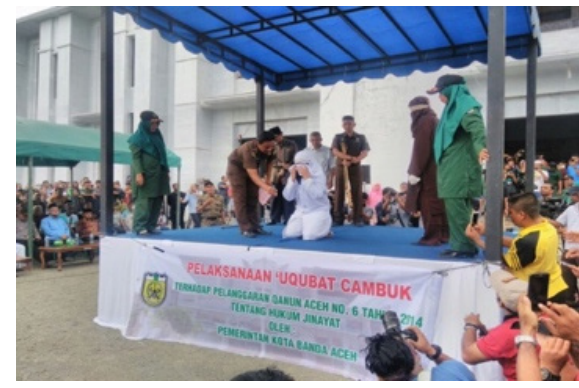

Photo 3. Modusaceh.co (20 April 2018)

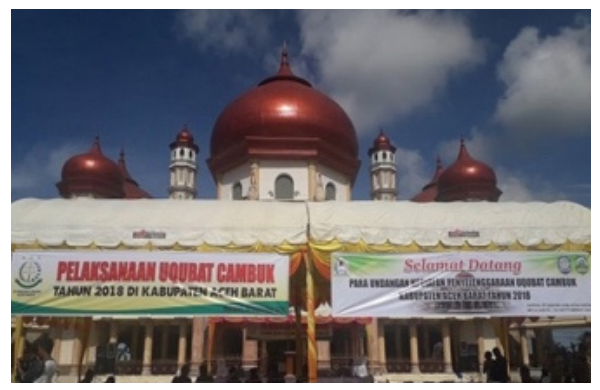

Photo 5. Serambinews.com

(20 September 2018)

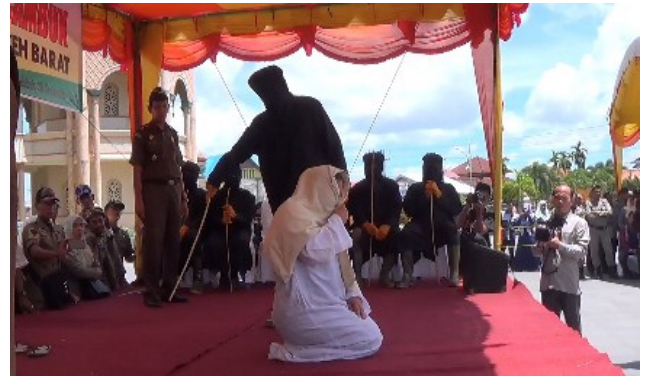

Photo 4. Modusaceh.co ( 20 September 2018)

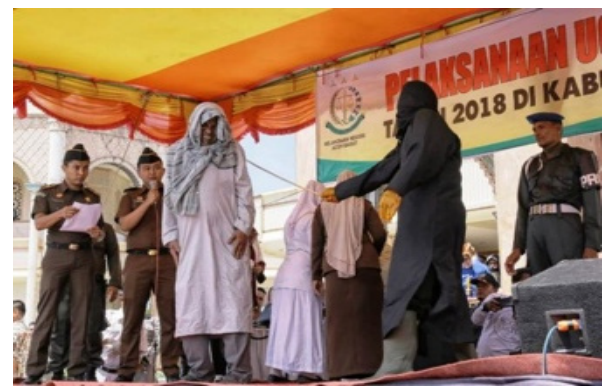

Photo 6. Waspadaaceh.com

(20 September 2018) 


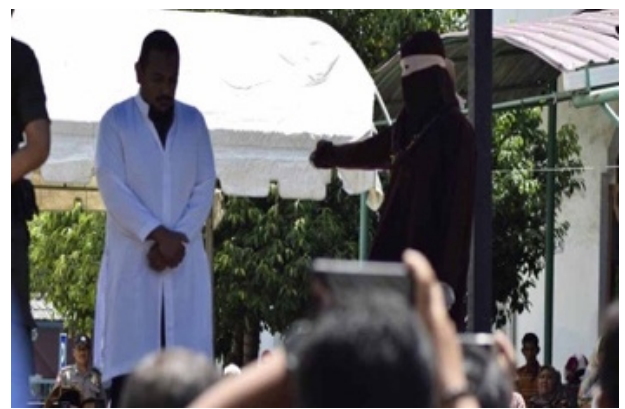

Photo 7. Beritakini.co

( 29 October 2018)

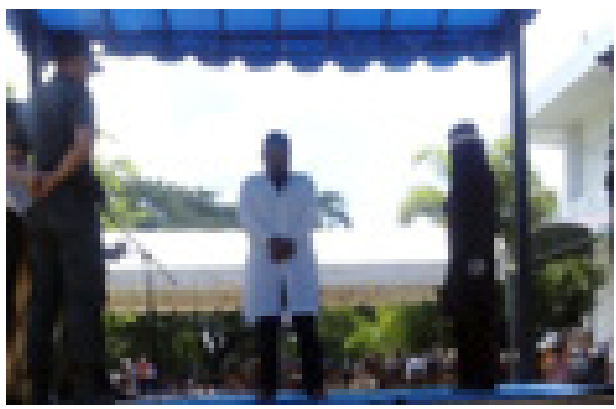

Photo 8. Waspadaaceh.com (29 October 2018)

Female convicts were also often immortalized through photos with expressions of tears, covering their faces in shame or even fainting due to pain. It was different from photos of male convicts with strong body language, without expression and blurring. However, this did not automatically negate that the male convicts were also used as the primary photo object in the five online media.

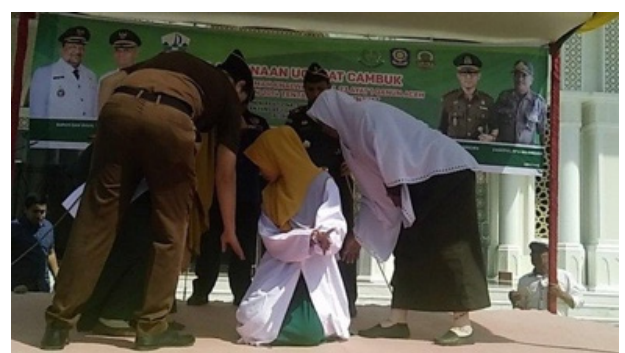

Photo 9. Serambinews.com

(2 August 2019)

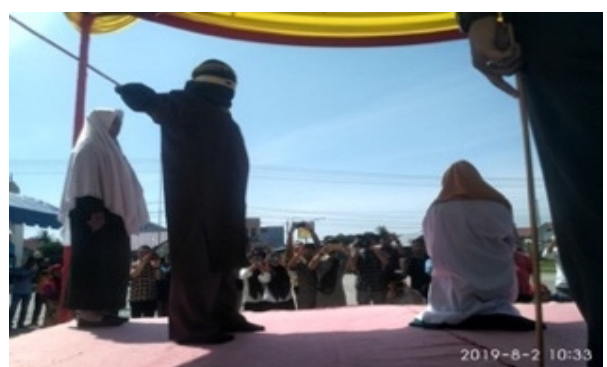

Photo 10. Modusaceh.co

(2 August 2019) 
Al-Balagh: Jurnal Dakwah dan Komunikasi,

Vol. 6, No. 1, January - June 2021, pp. 95 - 130, DOI: https://doi.org/10.22515/al-balagh.v6i1.3061

ISSN: 2527-5704 (P) ISSN: 2527-5682 (E)

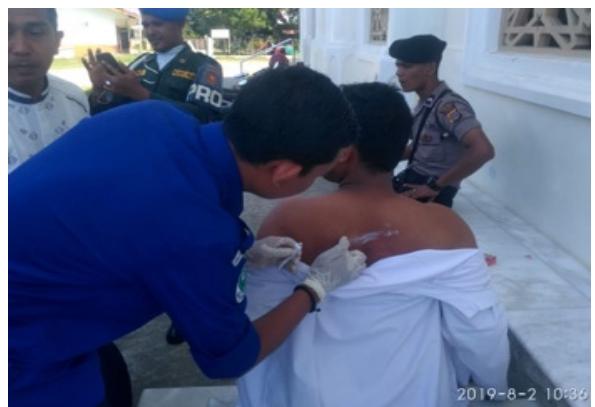

Photo 11. Modusaceh.co

(2 August 2019)

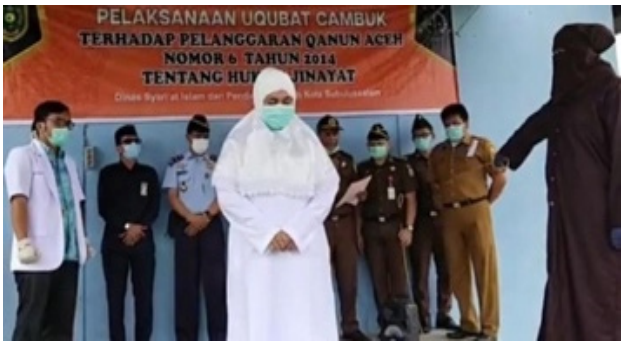

Photo 13. Beritakini.co

(7 April 2020)

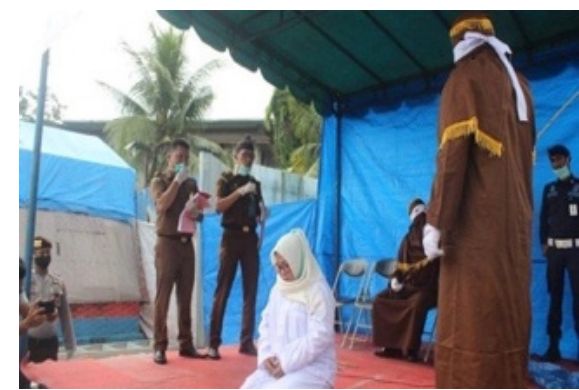

Photo 15. Serambinews.com (17 April 2020)

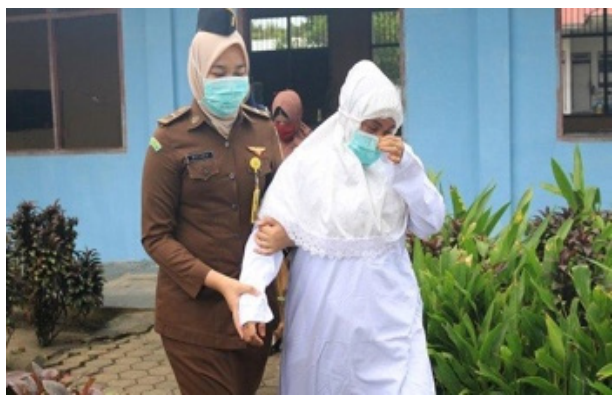

Photo 12. Serambinews.com

(7 April 2020)

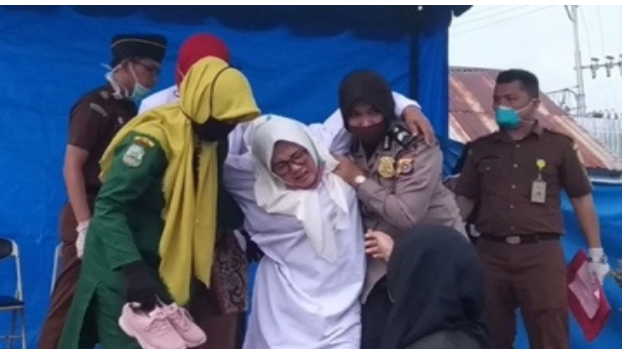

Photo 14. Beritakini.co

(17 April 2020)

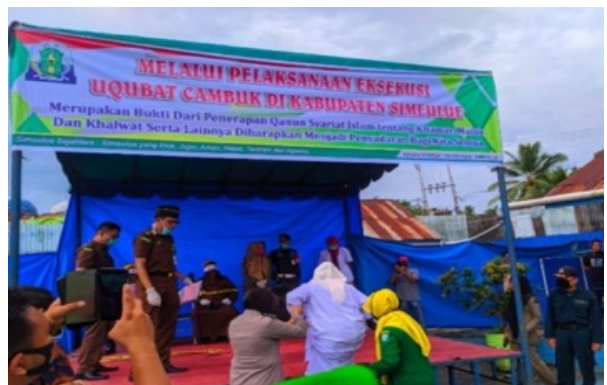

Photo 16. Modusaceh.com(17 April 2020)

Similar practices were implemented from 2018 to 2020. However, based on the findings in this study, photos of female convicts were not only exploited in cases of khalwat and ikbtilat, but have also been featured 
in the news of other cases. For example, it was used as an illustration of news discussing the caning regulation.

\section{The Attitude Of Journalists And Editors Towards Caning}

Central figures in the production of caning news are journalists and editors. Journalists as fact-gatherers have the flexibility to choose and report any information, angles, and people. Every journalist and editor has a background of knowledge and belief regarding the law of caning and Islamic law, and every media has a specific ideological background.

According to Stuart Hall (Storey, 2010), meaning construction by text producers involves the knowledge framework they already have regarding a topic and relates to the text production activity. This process is called encoding. Likewise, readers also construct the meaning of the text by matching it with their previous knowledge relating to the text. In this regard, if readers' knowledge of female convicts has been shaped and has the same meaning, the circulation of production and replication of reality's meaning will follow a similar pattern.

Through interviews, J1-J7 said that caning had high news value and a relatively large readership, especially news of khalwat and ikhtilat. The great potential of the convicted person to become the object of the caning coverage became a Standard Operating Procedure (SOP) for covering news of caning in the five media. However, to attract more viewers, J1-J7 mentioned that one effective way was to position female convicts as news objects, affix the labels with sensational nuances to the female convicts, and show their photos with various expressions and angles. The involvement of female convicts in crime was also interpreted by J1-J7 as something strange and should not have happened. It seems that because journalists felt odd seeing female offenders, the female convicts who received lashes in public attracted more media attention, especially with the labels of the offenders as wife and mother and their expression when crying, hysterical, 
begging not to be caned. Such news packaging had high value and the potential to attract the interest of many readers.

The stereotypes of female convicts as weak characters emotionally and mentally, and male convicts who were perceived as strong, tough, although they experienced difficulties, also affected how journalists presented the figures of male and female convicts in texts. J1 (interview 15 August 2018) said that although the male convicts also felt the pain, they did not want to show the pain. Hence, the male convicts who were ashamed by the case did not display any tormented expression. For J1 and his media, the male convict who looked strong had no news value.

These various forms of gender-based inequality resulted from discourse reflections from journalists, editors, and media itself. Not only journalists and editors concerned with this discourse, but also editors and media editorial policy. A recent survey revealed that Indonesian journalists considered editorial policy and journalist autonomy crucial job aspects (Willnat, Weaver, \& Choi, 2013). The discourse inside media determines how the portrayal of female convicts was selected, shaped, and disseminated. E1 (interview, 21 August 2019) said he often argued with other editors regarding certain limitations in presenting news. However, the editorial team refuted E1's arguments on the pretext that the practice was beneficial for the media. E1 admitted that he often succumbed to the wishes of online media editors by concluding that online media provided less leeway on moral issues.

Even though the news about the caning has unethical connotations, editors E1 and E2 both said that they both relied on ethical principles in editing the caning news. E2 did a layered check considering the impact after the news was published. E1 (interview, 21 August 2019) explained that he tended to avoid editing news about caning because, in online media culture, it was recommended that crime news be published sensationally. E1 and E2 were a small part of editors in many online media companies 
in Aceh. The ethical principles applied by E1 and E2 did not necessarily become a consideration for other media editors in the depiction of female convicts in the caning news. It is evident in several products of caning legal news in Aceh's online media, which included misrepresentations of both female and male offenders.

Power relation is not understood as a powerful domination mechanism over the powerless. Foucault (Guittar \& Carter, 2014) classified some instruments of the applied body discipline. Firstly, hierarchical observation and surveillance which is carried out constantly by monitoring all the subjects in it. In this study, journalists and editors carried out hierarchical observation and surveillance in the media context. This had implications for creating patterns of production of caning news that might be in accordance with the needs of the media, even though they must discriminate against certain groups. Secondly, normalizing judgment by comparing the subject's behavior with existing norms/moral standards and then punishing the subject if his behavior was not in accordance with those standards. In fact, there is a combination of the supervision and punishment method known as examination in several sources. In this context, the discourse formed by the five online media with various factors raises specific moral standards attached to the female convicts. Such representations positioned the female offenders and an indicator of the implementation of Islamic law, meaning that they must be regulated so that sexuality-based offenses would be decreased in Aceh.

\section{The Media Consumption OfThe Caning Execution News}

This pattern is seen through how readers/viewers consumed the discourse. However, in this study, the researchers did not find direct comments on the fifteen news stories included in this study. Readers' comments regarding the news about the caning execution were seen through their official social media accounts such as Facebook. The five 
media have their respective Facebook fan pages, namely Serambinews.com (662,665 followers), AJNN.net - Aceh Journal Nasional Network (34,135 followers), MODUS ACEH (235 followers), BERITAKINI.CO (23,354 followers), and Waspadaaceh.com (2,645 followers). The researchers only found three out of fifteen news stories in this study distributed through fan page accounts. Serambinews.com carried out all three: the news story of 20 April 2018 (34 comments, 55 shares, 947 emoticons); 2 August 2019 (10 comments, 12 shares, 40 emoticons); and 7 April 2020 (5 comments, eight shares, 56 emoticons).

The news stories on 20 April 2018 and 2 August 2019 in Serambinews. com provided information on the execution of caning in several cases, which were carried out against male and female convicts. However, both news stories used female convict photos as illustrations and female convicts as news angles. Based on the observations, there were several comments from readers addressing the female convicts.

\section{Dion Dion}

Yg merasa ngak co2k dpt d pastikan "PENDUKUNG APAM"

Figure 1. The Screenshot Of A Reader's Comment On Serambinews.com's Fan Page (20 April 2018 issue)

The researchers found that the readers' comments were directed at female convicts, namely through using the diction of 'apam.' Explicitly, apam is a type of pancake in Aceh. However, implicitly, apam often connotes female genitals. This diction had also been observed that social media users often used issues of sexuality regarding the role of women in it, such as khalwat, ikhtilath, and online prostitution. Then in the news link on 2 August 2 2019, the reader's comments added to the "suffering" experienced by female convicts by saying words expressing negative nuances. 
Suherman Megaloman

Ma di merintih,lage i kheun..oouhh noo...oohh yees...yees, aaatiiiit...reulouh looem

..yees...

M. Husni Kahar

KENA CAMBUK MERINTIH KESAKITAN....SEWAKTU BERBUAT ENAK AMA

KEKASIHNYA MERINTIH KE..ENAKAN...HAHAHAHAHA BOEH LOEM SIGO !

Samsul Kamal

Ya jelas sakit kalo dicambuk, mna mungkin enak...

Yg enak itu ya brbuat wik wik

Figure 2. The Screenshot Of A Reader's Comment On Serambinews.com's Fan Page (2 August 2019 issue).

Furthermore, on 7 April 2020, Serambinews.com published a story that only made female convicts the news object. The readers provided a detailed response to female convicts, even though the cases involved male convicts.

\section{ลै. Hazman Hafidz}

Semoga isteri istri kita, dijauhi dr sifat buruk itu..

Like- Reply - 1 y

\section{Apa Pungo}

Padaaaang,ambo dosa potong ayam putih, hapuh dosanyo.

Meukawen lom ngon padang

Like-Reply - 1 y

Q7. Adam Naah

Alah hai cupo..gadoh jok apam keu ase pungo...

Figure 3. The Screenshot Of A Reader's Comment On Serambinews.com's Fan Page (2 August 2019 issue)

The researchers found no comments that showed empathy for the convicted or challenged the narrative built by Serambinews.com. This argument is supported through findings in Fitri \& Haekal's research 
(2021). Using thematic analysis, they found at least four dominant themes discussed by the publsic in the news link on the caning execution on the Serambinews.com's Facebook fan page: 1) The readers came up with the idea of extreme punishment for offenders; 2) Cursing appeared more frequently in the news about khalwath and ikbtilath cases; 3) Public concerned about the convict's activities; and 4) The readers showed a positive stance against Islamic law and caning. In some links, readers responded to the news using the word 'apam', even though the cases reported have nothing to do with the execution of caning involving female convicts. The finding also confirmed the stigma of women as the cause of sexual misconduct, even though the existing cases included the role of men in it.

Readers' response in consuming media is identical to the methods conveyed by the media. This response is indicated as the result of normalization carried out by the media. Similar patterns contribute to the creation of knowledge that is identical to what the media convey. In the news link below, some readers seemed to focus on talking about female convicts. For example, they commented on the figure of a wife, even the diction of 'apam' was still applied, especially in responding to issues of sexuality. This finding does not mean that media and readers do not target men, but female convicts experience it more frequently. Serambinews.com broadcasted the execution of the female convict directly on its Facebook fan page. The post resulted in 440 comments and 684 emoticons. 


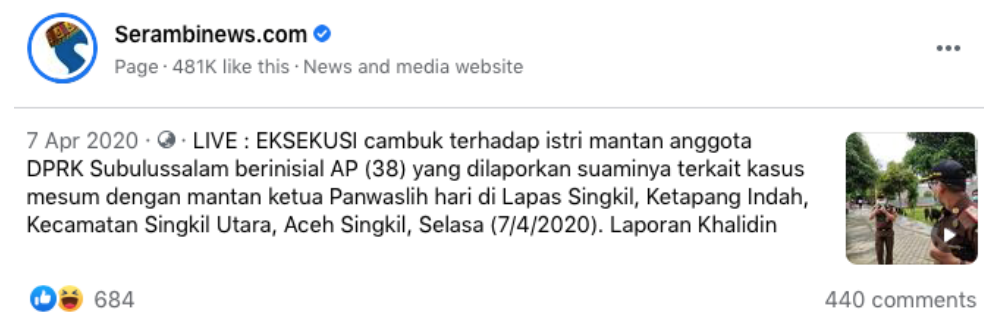

Figure 4. The Live Broadcast Screenshot Of The Female Convict Caning Execution (Serambinews.com's Facebook Fan Page, 2 August 2019).

Today's social media have an essential role in promoting their news to the public (Tandoc, Jr \& Vos, 2016). The five online media utilized social media in increasing the intensity and frequency of interactions, thus indirectly benefiting the media economy (Ziegele, Weber, Quiring, \& Breiner, 2018). However, Nielsen \& Schrøder (2014) underlined that in several large countries such as Denmark, France, and the UK, social media tends to be personal, not based on public interests. Social media users only participate in sharing, commenting, or publishing their own stories. This phenomenon is different from the findings of this study. For example, it was revealed through an interview with J4 that in the media where he worked, the editor deliberately created several social media accounts whose task was to provoke reader interaction. The editor on some Facebook accounts intentionally shared news links and added confrontational captions that trigger social media users to comment. J4 presumed that this pattern could invite social media users to contribute their clicks on the links.

However, the ideology of the mass media influencing the production and consumption of narrative also forms a new reality about an event. The study of Nasution (2017) showed that the ideological interests between different media in packaging the similar fact affect its manifestation. Likewise, in this study, the ideology of the five media in packaging one caning execution led to the production of different realities. The 
phenomenon of media content in the contemporary era, which is closely related to discrimination, marginalization, and so forth, is also considered incompatible with the spirit of Islamic journalism in providing benefits to the public (Minan, 2016).

\section{External Factors Influencing The Discourse Of Female Convicts In The Coverage Of Caning}

The increasing number of online media in Indonesia, especially Aceh, produce even more arduous competition. Online media compete with each other to publish faster and more unique stories to attract more readers. This pattern certainly follows the millennial generation's development, where most internet users are more interested in consuming information presented in a unique, bombastic, and sensational way. Although the caning is not new to local online media in Aceh, this issue still has readers, both at local, national, and international scales. Competition between online media is currently determined by Search Engine Optimization (SEO). According to Ledford (2009), SEO is a technique of adjusting a website to appear and rank better in search engines. SEO refers to online media traffic. Therefore SEO has a significant role in the online-based media industry. Search engines use some criteria to determine rankings based on website popularity, keyword text, link context, title, hashtags, and so forth (Dick, 2011). Online media implement this practice to make search engines such as Google track their contents quickly and lead them to go viral. The more viral the news is online, the more it attracts readers, and the more benefits the online media will get. As stated by a representative of AJI Banda Aceh:

"In the digital era, the media's highest position is no longer the managing editor, but SEO...so that the keywords are easy to find on Google. The goal is to add AdSense through clickbait. The title is bombastic, and the content is ordinary." 
(A representative of AJI Banda Aceh, interview 15 August 2018).

Instead of focusing on the quality of news, SEO has created a tendency for media workers to meet the standard of SEO effectiveness, such as Google (Dick, 2011). This phenomenon has triggered the emergence of many ethical problems in online journalism practices. Ethical questions often challenge the issue of caning news on online media. This is also a challenge for journalists and online media to apply the Journalistic Code of Ethics (Kode Etik Jurnalistik/KEJ) in the digital era. The KEJ, which was passed through Press Law No. 40/1999, did not specifically mention the rules of online journalism, but if examined further, the existing KEJ is still relevant to journalism in the digital era. According to a representative of AJI Banda Aceh (15-8-2018), when a journalist works in online media upholds the KEJ, at least the journalist has guidelines that can minimize unethical practices. He further stated that all journalists must pay attention to the impact of written news and be aware of reducing the negative impact. Journalists often ignore this ideal practice, given that the media has an economic function. Moreover, because many journalists do not have a journalistic background and are reluctant to continue studying journalism, the problems would potentially continue to persist.

Based on the findings, the irregularities in the discourse discriminating against female convicts were hardly ever discussed by the government and the mass media in Aceh. Based on the interviews, the journalists and the editors claimed that they never received the intervention or disapproval from anyone regarding the news of the published female convicts. This kind of public response could be caused by the existing public perception in the Acehnese society that women were considered inappropriate parties to commit such heinous acts or by the effects of the discourse that the media spread. 
For Foucault, power can never be separated from knowledge, in which the combination of the two results in discourse. Knowledge is not pure and neutral, but the knowledge legitimized by power becomes a form of how the normalization of power occurs in society. This power ultimately normalizes the subject in speaking, thinking, and acting, following the ongoing dominant power (Lilja \& Vinthagen, 2014). Foucault's ideas, known as genealogy, show how certain discourses gain authority and function as rules and what factors determine them, and how specific topics should be thematized. This formula is then manifested as the institutions involved. Through discourse, power and knowledge aim to discipline the subject immaterially. The intended subject can be anyone, like individuals, institutions, government, media, and so forth. Harcup \& O'Neill (2017) explained that the standard of news value could come from what the public wants and reflect the institution's values.

Although there are limitations to editorial policies that require employees to prioritize humanist values, the fierce competition among online media makes this difficult to do. Thus, online media still needs to focus on female convicts in the caning news. Online media could gain more profits by exploiting the convicted women. It further supports the assumption that the Qanun Jinayah discourse on online media was still detrimental to women.

This repetitive scheme could motivate the district administration in Aceh to discuss or issue various policies that were discriminative against women, for example, the 2013 regional regulation on "prohibition of straddling" for women getting a ride on motorbikes in Lhokseumawe, the discourse on enforcing curfews for women in Banda Aceh in 2015, and the discourse on banning sitting at the same table with non-mahram in 2018 in Bireuen Regency, restrictions on women's movement to enter certain areas, raids on women's clothing or virginity tests. The charges were carried out by Wilayatul Hisbah (WH) as the sharia police also more targeted women. 
These policies created feelings of worry, fear, discomfort, even shame, and isolation for women. Women involved in crimes based on Qanun Jinayah also experience psychological and social pressure, such as feeling alienated, humiliated, and depressed. Some examples of the rules above emphasized that media objectifying female convicts contributed to the knowledge creation that women were used as indicators of the implementation of Islamic law in Aceh. Women were also considered a threat because they were considered a source of violations of Islamic law, especially in cases of sexuality. Such a discourse certainly does not appear instantly. The contribution of knowledge produced and reproduced by the mass media is one of the reasons why women are still being marginalized. Previously, the marginalization and discrimination of women in media were carried out before the sentence was passed on.

Also, there are concerns that the discourse of female convicts in online media can potentially initiate some fanatical Islamic organizations to persecute violators of Islamic law, especially khalwat and ikhtilath, in a vigilante mode. Various pieces of evidence of the pre-execution carried out by the community, and Islamic mass organizations were more or less part of the implications of the narrative formed by the mass media, which contained negative stigma and stereotypes towards female convicts.

\section{CONCLUSION AND SUGGESTION}

\section{Conclusion}

From 2018 to July 2020, the five online media still positioned female convicts as the object of news that was economically beneficial. Female convicts were represented as criminals in cases like khalwat and ikhtilath. Female convicts were also represented as weak figures, the second sex, and covered with sensational narratives. This could increase the number of clicks and give economic benefits to online media. The emergence of media analytics which refers to the number of clicks, places a burden 
on the media to accentuate certain aspects of the publication. Editorial decisions affected the success of the media in generating traffic.

Besides, the formation of discourse on female convicts is also influenced by the media competition in SEO. On another side, the researcher did not find any counter-reactions from readers regarding the discourses of female convicts published on five media websites. It seems that the practice was considered normal, so it did not have to be questioned anymore. This indicates that power relations based on patriarchal ideology have been accepted and regarded as natural. This research also suggested that the discourse that discriminates against female convicts has benefited the media.

\section{Suggestion}

Online media as part of the mass media should carry out a social surveillance function. Ideally, online media take on that role by creating objective reporting narratives related to Islamic law, caning, and female convicts. Online media should participate in evaluating all forms of Islamic sharia policy practices, especially concerning cases experienced by female and male convicts, so that there are no more discriminatory practices against certain genders.

One of the significant points that online media workers must consider is the importance of working together with journalist associations. It is because journalist associations often facilitate the training and workshops for the capacity building of their members. Producing news is concerned with writing skills and the ability to understand problems from a particular perspective, including gender and human rights.

The researchers recommend further studies to see the discourse of female convicts in the caning news about caning by using other data analysis techniques. For example, they may discover this issue further by utilizing Theo Van Leeuwen's text (Social Actors Approach) or examining 
the historical realm of the legal discourse development of caning through the lens of Discourse Historical Approach (Ruth Wodak). We also encourage further studies to perform comparative media analysis to examine the differences of representations across media outlets. It is expected to get a more comprehensive picture of the media representation of female convicts in Aceh.

\section{Acknowledgment}

This research received a grant from the Directorate of Islamic Higher Education, the Directorate General of Islamic Education, the Ministry of Religious Affairs of Indonesia in 2019.

\section{REFERENCES}

Amri, S. (2019). Analisis Framing Pemberitaan Hukum Cambuk Pada Media Serambi Indonesia Di Aceh. (Thesis Master: Unpublished). Semarang: Master Program In Communication Science Diponegoro University.

Bahri, S. (2013). Konsep Implementasi Syariat Islam Di Aceh. Kanun Jurnal Ilmu Hukum, 15(2), 313-338. http:/ /202.4.186.66/kanun/article/ view/6174

Brennan, P. K., \& Vandenberg, A. L. (2009). Depictions Of Female Offenders In Front-Page Newspaper Stories: The Importance Of Race/Ethnicity, International Journal of Social Inquiry, 2(2), 141-175

Chiu, W., \& Lu, K. (2015). Paradigmatic Relations And Syntagmatic Relations: How Are They Related? Proceedings Of The Association For Information Science And Technology, 52(1), 1-4. https://doi. org/10.1002/pra2.2015.1450520100122

Dawson, P. (2014). Our Anonymous Online Research Participants Are Not Always Anonymous: Is This A Problem? British Journal Of Educational Technology, 45(3), 428-437. https://doi.org/10.1111/ bjet.12144 
Dedees, A. R. (2014). No Perempuan Seksi Dalam Jaring Korupsi. Jurnal Ilmu Komunikasi, 11(1), 37-54. https://doi.org/10.24002/jik. v11i1.383

Dick, M. (2011). Search Engine Optimisation In UK News Production. Journalism Practice, 5(4), 462-477. https://doi.org/10.1080/175127 86.2010 .551020

Fairclough, N., \& Fairclough, I. (2018). A Procedural Approach To Ethical Critique In CDA. Critical Discourse Studies, 15(2), 169-185. https:// doi.org/10.1080/17405904.2018.1427121

Fakhri, F., \& Juanda, H. (2020). Analisis Foto Jurnalistik Pada Kantor Berita Agence France Presse (AFP) Tentang Penerapan Syariat Islam Di Aceh Tahun 2017. Jurnal Al-Bayan: Media Kajian Dan Pengembangan Ilmu Dakwah, 26(1), 77-96. https://doi.org/10.22373/albayan. v26i1.7857

Fitri, A., \& Haekal, M. (2021). Hukum Cambuk \& Opini Publik: Analisis Tematik Tanggapan Netizen Terhadap Berita Pelanggaran Syariat Islam Di Akun Facebook Media Massa. Source: Jurnal Ilmu Komunikasi, 7(1), 21-31. https://doi.org/10.35308/source. v7i1.3285

Graham, L. J. (2011). The Product Of Text And 'Other'statements: Discourse Analysis And The Critical Use Of Foucault. Educational Philosophy And Theory, 43(6), 663-674. https://doi.org/10.1111/ j.1469-5812.2010.00698.x

Guittar, S. G., \& Carter, S. K. (2014). Disciplining The Ethical Couponer: A Foucauldian Analysis Of Online Interactions. Foucault Studies, 18, 131-153. https://doi.org/10.22439/fs.v0i18.4656

Hadiati, E., Abdullah, I., \& Udasmoro, W. (2013). Konstruksi Media Terhadap Pemberitaan Kasus Perempuan Koruptor. Al-Ulum, 13(2), 345-372.

Harcup, T., \& O'neill, D. (2017). What Is News? News Values Revisited (Again). Journalism Studies, 18(12), 1470-1488. https://doi.org/10. 1080/1461670X.2016.1150193

Hegarty, P., \& Bruckmüller, S. (2013). Asymmetric Explanations Of Group Differences: Experimental Evidence Of Foucault's Disciplinary Power. Social And Personality Psychology Compass, 7(3), 176-186. https://doi.org/10.1111/spc3.12017 
Human Rights Watch. (2010). Menegakkan Moralitas Pelanggaran Dalam Penerapan Syariah Di Aceh, Indonesia. New York, United States: Human Rights Watch.

Jia, S., Lansdall-Welfare, T., Sudhahar, S., Carter, C., \& Cristianini, N. (2016). Women Are Seen More Than Heard In Online Newspapers. PloS One, 11(2), e0148434. https://doi.org/10.1371/journal. pone. 0148434

Juliani, R. (2018). Pemberitaan Media Asing Mengenai Hukum Cambuk Gay Di Aceh. Source: Jurnal Ilmu Komunikasi, 3(2). 209-220, https:/ / doi.org/10.35308/source.v4i2.920

Kristensen, K. (2013). Michel Foucault On Bio-Power And Biopolitics. Retrieved March 30, 2020, from helda.helsinki.fi website: https:// helda.helsinki.fi/handle/10138/39514

Ledford, J. L. (2009). SEO: Search Engine Optimization Bible (Vol. 29). Hoboken, New Jersey, United States: Wiley

Lilja, M., \& Vinthagen, S. (2014). Sovereign Power, Disciplinary Power And Biopower: Resisting What Power With What Resistance? Journal Of Political Power, 7(1), 107-126. https://doi.org/10.1080/ 2158379X.2014.889403

Littlejohn, S. W. \& Foss, K. A. (2010). Theories Of Human Communication. Long Grove, Illinois: Waveland Press, Inc.

Maulina, P. (2017). Pembungkaman Terhadap Perempuan Dalam Teks Pemberitaan Syariat Islam. Bidayah: Studi Ilmu-Imu Keislaman, 8(1), 120-133.

Minan, I. (2016). Relasi Media Massa Dan Dakwah Kontemporer. AlBalagh: Jurnal Dakwah Dan Komunikasi, 1(2), 197-214. https://doi. org/10.22515/balagh.v1i2.349

Muktiyo, W. (2017). MenggugatStereotif "Perempuan Sempurna”: Framing Media Terhadap Perempuan Pelaku Tindak Kekerasan. Palastren Jurnal Studi Gender, 10(2), 248-272. https://doi.org/10.21043/ palastren.v10i2.2610

Murtiningsih, B. S. E., Advenita, G. E. M., \& Ikom, S. (2017). Representation Of Patriarchal Culture In New Media: A Case Study Of News And Advertisement On Tribunnews. Com. Mediterranean Journal Of Social Sciences, 8(3), 143-154. https://doi.org/10.5901/mjss.2017. v8n3p143 
Nasution, I. F. A. (2017). Islam Agama Teror? (Analisis Pembingkaian Berita Media Online Kompas. Com Dalam Kasus Charlie Hebdo). Al-Balagh: Jurnal Dakwah Dan Komunikasi, 2(1), 45-62. https://doi. org/10.22515/balagh.v2i1.753

Nielsen, R. K., \& Schrøder, K. C. (2014). The Relative Importance Of Social Media For Accessing, Finding, And Engaging With News: An Eight-Country Cross-Media Comparison. Digital Journalism, 2(4), 472-489. https://doi.org/10.1080/21670811.2013.872420

O’Donnell, B. (2016). Male And Female Murderers In Newspapers: Are They Portrayed Differently? Fields: Journal Of Huddersfield Student Research, 2(1), 45-67. https://search.informit.org/doi/10.3316/ INFORMIT.697773212493660

Rabionet, S. E. (2011). How I Learned To Design And Conduct SemiStructured Interviews: An Ongoing And Continuous Journey. Qualitative Report, 16(2), 563-566. https://doi.org/10.46743/2160$3715 / 2011.1070$

Satpol PP \& WH Kota Banda Aceh. (2020). Penyelesaian Kasus Pelanggaran Perda/ Qanun Syariat di Kota Banda Aceh. Retrieved January 30, 2021, from data.bandaacehkota.go.id website: https://data.bandaacehkota.go.id/index.php/dataset/single/ penyelesaian-kasus-pelanggaran-perda-qanun-syariat-di-kotabanda-aceh/354edfdf-133a-4d2b-b39d-f59e73e0c8a2.

Shaw, A. (2017). Encoding And Decoding Affordances: Stuart Hall And Interactive Media Technologies. Media, Culture \& Society, 39(4), 592-602. https://doi.org/10.1177/0163443717692741

Storey, J. (2010). Cultural Studies And The Study Of Popular Culture (3rd Ed). Edinburgh, United Kingdom: Edinburgh University Press.

Tandoc, Jr., E. C., \& Vos, T. P. (2016). The Journalist Is Marketing The News: Social Media In The Gatekeeping Process. Journalism Practice, 10(8), 950-966. https://doi.org/10.1080/17512786.2015 .1087811

Willnat, L., Weaver, D. H., \& Choi, J. (2013). The Global Journalist In The Twenty-First Century: A Cross-National Study Of Journalistic Competencies. Journalism Practice, 7(2), 163-183. https:/ / doi.org/1 0.1080/17512786.2012.753210 
Wright, K. A. M., \& Holland, J. (2014). Leadership And The Media: Gendered Framings Of Julia Gillard's 'Sexism And Misogyny' Speech. Australian Journal Of Political Science, 49(3), 455-468. https://doi.org/10.1080/10361146.2014.929089

Ziegele, M., Weber, M., Quiring, O., \& Breiner, T. (2018). The Dynamics Of Online News Discussions: Effects Of News Articles And Reader Comments On Users' Involvement, Willingness To Participate, And The Civility Of Their Contributions. Information, Communication \& Society, 21(10), 1419-1435. https://doi.org/10.10 80/1369118X.2017.1324505 
Al-Balagh: Jurnal Dakwah dan Komunikasi,

Vol. 6, No. 1, January - June 2021, pp. 95 - 130, DOI: https://doi.org/10.22515/al-balagh.v6i1.3061

ISSN: 2527-5704 (P) ISSN: 2527-5682 (E) 